\title{
GASTRIC ADENOCARCINOMA TRENDS IN THE CENTRAL REGION OF RIO GRANDE DO SUL (SOUTHERN BRAZIL): what has changed in 25 years?
}

\author{
Alexandre RAMPAZZO ${ }^{1,2}$, Guilherme Lang MOTTA ${ }^{1}$, Kalil FONTANA ${ }^{1}$ and \\ Renato B. FAGUNDES ${ }^{1,3}$
}

\begin{abstract}
Context - Gastric cancer is the fourth most common malignancy in the world. Its incidence varies greatly by geographic region. The highest rate is in Eastern Asia, mainly in Japan and China. In Brazil, gastric cancer is the third most common cancer in males and the fifth most common cancer in females. Rio Grande do Sul state, in Southern Brazil, has similar figures. The main histological type of gastric cancer is adenocarcinoma. Objective - To assess the trends of this cancer over 25 years in a reference center in central Rio Grande do Sul. Methods - We reviewed the records of upper gastrointestinal endoscopies performed at the University Hospital of Santa Maria, RS, between 1986 and 2010. We evaluated the incidence, age and gender distribution, anatomical subsite and histological subtype of gastric cancer throughout this 25-year period. Results - We identified histologically confirmed primary gastric adenocarcinoma in $335(1.6 \%)$ of the 20,521 patients who underwent upper gastrointestinal endoscopy during the study period. The mean age of patients was 62.4 ( \pm 13.0 ) years, and $67.8 \%$ were male (a male: female ratio of $2.0: 1$ ). Cardia cancer accounted for $14.3 \%$ of the cases, and non-cardia cancer accounted for $85.7 \%$. According to Lauren's classification, $48.1 \%$ were intestinal subtype and $40.9 \%$ were diffuse subtype. There were no differences in mean age or gender distribution by anatomical location or histological subtype. There was also no difference in the proportions of histological subtypes by anatomical location. Over the 25-year period, there was no change in the anatomical distribution of tumors, but there was a significant decrease in the intestinal subtype and a steady increase in the diffuse subtype $(P=0.02)$. The subset of 39 patients $(11.6 \%)$ who presented at $<45$ years of age was more likely to be female and to have tumors of the diffuse subtype than was the total series of patients. Conclusions - Over this 25-year period, there were no significant trends in age, gender distribution, or the proportions of cardia and non-cardia gastric adenocarcinomas in this series of patients from Southern Brazil. There was a significant decrease in the intestinal subtype and a steady increase in the diffuse subtype of this malignancy. In patients under 45 years old, gastric cancer was more frequent in women, and the diffuse subtype predominated.
\end{abstract}

HEADINGS - Stomach neoplasms, epidemiology. Adenocarcinoma. Rio Grande do Sul.

\section{INTRODUCTION}

Gastric cancer is the fourth most common malignancy in the world and the second-leading cause of cancer death in both sexes worldwide. More than $70 \%$ of cases occur in developing countries, and half of the world total occurs in Eastern Asia alone, mainly in Japan and China ${ }^{(3,10,30)}$. In Brazil, the incidence of gastric cancer has declined in both sexes over the past 3 decades, but it is still the third and the fifth most common incident cancer in males and females, respectively ${ }^{(5)}$. Between 1986 and 2008, the national adjusted mortality rates per 100,000 inhabitants fell from 14.7 to $9.9(32.7 \%)$ in men and from 6.3 to 4.2
$(33.3 \%)$ in women. In the same period, Rio Grande do Sul State (RS) has experienced similar trends. The adjusted mortality rates for 100,000 inhabitants, in RS fell from 17.0 to $9.2(45.9 \%)$ in men and from 7.5 to $3.6(52.0 \%)$ in women ${ }^{(13)}$. Epidemiological data from many areas in the world have suggested a shift in the location of gastric cancers in the last decades, with an increase in the incidence of cancer of the cardia and gastroesophageal junction ${ }^{(5,9,12,31)}$, as well as a change in the histological presentation, with an increase in the diffuse type in some populations ${ }^{(5,24,29)}$.

The aim of this study was to assess the trends of gastric adenocarcinoma in the central region of Rio Grande do Sul State over of the past 25 years, seeking

'Departamento de Clínica Médica, Universidade Federal de Santa Maria, RS: ${ }^{2}$ Hospital Universitário, Universidade Federal de Santa Maria, RS; ${ }^{3}$ Programa de Pós-Graduação: Ciências em Gastroenterologia e Hepatologia, Faculdade de Medicina, Universidade Federal do Rio Grande do Sul, Porto Alegre, RS, Brasil.

Correspondence: Dr. Renato Borges Fagundes - Departamento de Clínica Médica - Centro de Ciências da Saúde - Universidade Federal de Santa Maria - Campus Universitário - 97105-900 - Santa Maria, RS, Brazil. E-mail: fagundesrb@gmail.com 
to identify changes in the occurrence of this cancer in relation to age, gender, anatomical location and histological subtype.

\section{METHODS}

We reviewed the records of all patients at the University Hospital of Santa Maria who underwent upper gastrointestinal endoscopy from January 1986 to December 2010 and had a diagnosis of gastric cancer. Patients with a diagnosis of primary gastric adenocarcinoma confirmed by histopathological examination were selected for the study. Patients with a diagnosis of distal esophageal adenocarcinoma, gastric malignancy other than adenocarcinoma, gastric metastases, and benign gastric tumors were excluded.

We recorded each patient's age and sex, as well as the anatomical location and histological subtype of each tumor. We defined cardia cancer as a lesion primarily involving the area between $1.0 \mathrm{~cm}$ proximal and $2.0 \mathrm{~cm}$ distal to the gastroesophageal junction ${ }^{(19)}$. We classified lesions primarily involving the fundus, body or antrum as non-cardia cancers. We used Lauren's classification of diffuse and intestinal histological subtypes, based on guidelines from the World Health Organization $^{(5,15,16)}$. We grouped the patients in 5-year time periods to evaluate time trends.

The Chi-square test and the Fisher's exact test were used,

TABLE 1. Frequency of gastric adenocarcinoma between 1986 and 2010

\begin{tabular}{cccc}
\hline Period & $\begin{array}{c}\text { Gastric } \\
\text { adenocarcinoma } \\
\text { cases }\end{array}$ & $\begin{array}{c}\text { Upper } \\
\text { gastrointestinal } \\
\text { endoscopy exams }\end{array}$ & $\begin{array}{c}\text { Frequency } \\
(\%)\end{array}$ \\
\hline $1986-1990$ & 24 & 1148 & 2.1 \\
$1991-1995$ & 60 & 4530 & 1.3 \\
$1996-2000$ & 87 & 5661 & 1.5 \\
$2001-2005$ & 71 & 4678 & 1.5 \\
$2006-2010$ & 93 & 4504 & 2.1 \\
\hline Total & 335 & 20521 & 1.6 \\
$(1986-2010)$ & & &
\end{tabular}

as appropriate, to test the associations between age, gender, tumor location and histological subtypes and occurrence of gastric cancer. Trend analyses were performed by the Mantel test for trend. Data were analyzed with SPSS 18, and $\alpha<0.05$ was considered statistically significant.

\section{RESULTS}

A total of 20,521 upper GI endoscopies were performed at the University Hospital of Santa Maria during the 25-year study period. We identified 335 patients with a primary diagnosis of gastric adenocarcinoma, for an overall frequency of $1.6 \%$. The frequency of detection by 5 -year periods is shown in Table 1. There was no significant trend in the frequency of detection over time $(P=0.089)$.

The mean age of patients was $62( \pm 13)$ years, with a range from 23 to 103 years. The mean age of men was $63( \pm 12)$, ranging from 32 to 85 years, and the mean age of women was $61( \pm 16)$, ranging from 23 to 103 years. Of the 335 cases, $227(67.8 \%)$ were males and $108(32.2 \%)$ were females, for a male:female ratio of 2.1:1. No significant changes were observed in mean age, or the distribution of the disease by gender over the 25 years of the study (Table 2).

Forty-eight $(14.3 \%)$ of the tumors were located in the cardia, $11(3.3 \%)$ in the fundus, $96(28.7 \%)$ in the body, $51(15.2 \%)$ in both the body and antrum, and $129(38.5 \%)$ in the antrum. Thus $48(14.3 \%)$ were cardia cancers and $287(85.7 \%)$ were non-cardia cancers. Analyzed by gender, $44 / 227(19.4 \%)$ of the male cases and $17 / 108(15.7 \%)$ of the female cases presented in the cardia $(P=0.5)$. We observed no significant change in the relative frequency of cardia and non-cardia tumors over time $(P=0.6)$.

There was an overall predominance of the intestinal histological subtype $(54.0 \%$ of classified tumors) over the diffuse subtype $(46.0 \%)$, but the proportion of diffuse tumors increased significantly over the 25 -year time period of the study $(P=0.02)$ (Table 3$)$. There was no statistically significant difference in the distribution of the histological subtypes by the anatomical location of the lesion, overall or over time (data not shown).

TABLE 2. Time trends in age, gender, anatomical location and histological subtype of gastric adenocarcinoma between 1986 and 2010

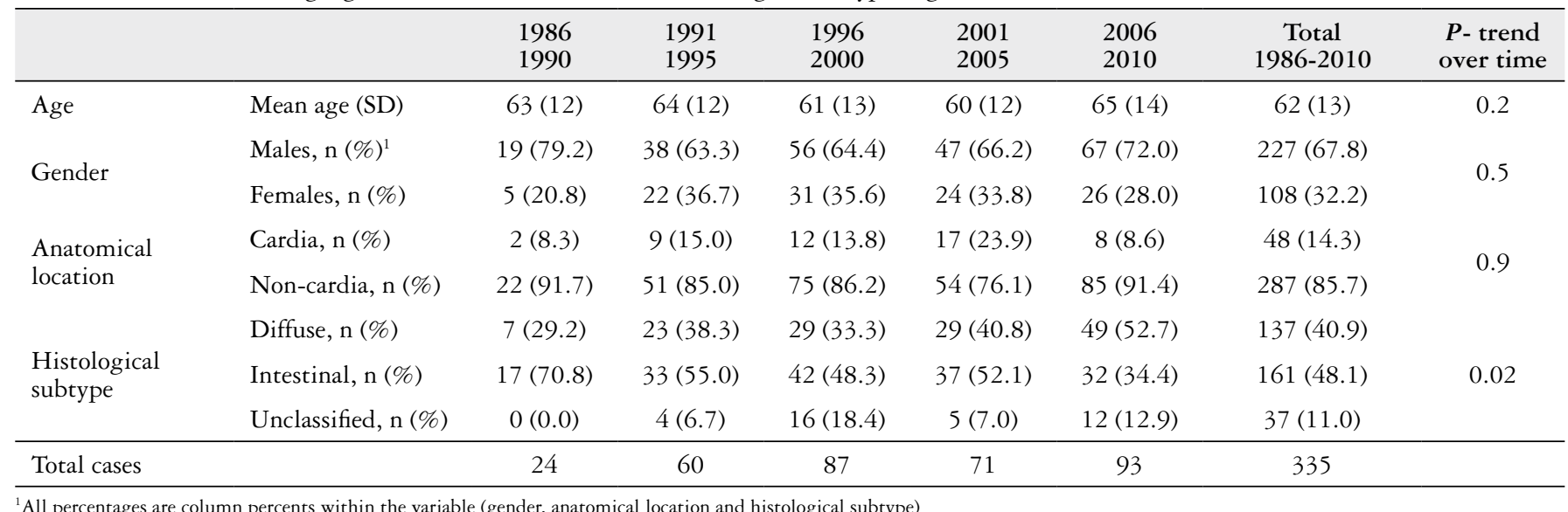


TABLE 3. Comparison of cases $<45$ and $\geq 45$ years old

\begin{tabular}{|c|c|c|c|c|c|}
\hline & & $\begin{aligned} & \text { Cases } \\
< & 45 \text { years }\end{aligned}$ & $\begin{aligned} & \text { Cases } \\
\geq & 45 \text { years }\end{aligned}$ & Total & $P^{(2)}$ \\
\hline \multirow{2}{*}{ Gender } & Males, $\mathrm{n}(\%)^{1}$ & $17(43.6)$ & $210(70.9)$ & 227 & \multirow{2}{*}{0.0} \\
\hline & Females, n (\%) & $22(56.4)$ & $86(29.1)$ & 108 & \\
\hline \multirow{2}{*}{$\begin{array}{l}\text { Anatomical } \\
\text { location }\end{array}$} & Cardia, n (\%) & $4(10.3)$ & $44(14.9)$ & 48 & \multirow{2}{*}{0.6} \\
\hline & Non-cardia, n (\%) & $35(89.7)$ & $252(85.1)$ & 287 & \\
\hline \multirow{3}{*}{$\begin{array}{l}\text { Histological } \\
\text { subtype }\end{array}$} & Diffuse, n (\%) & $20(51.3)$ & $117(39.5)$ & 137 & \multirow{3}{*}{0.0} \\
\hline & Intestinal, n (\%) & $11(28.2)$ & $150(50.7)$ & 161 & \\
\hline & Unclassified, n (\%) & $8(20.5)$ & $29(9.8)$ & 37 & \\
\hline Total cases & & 39 & 296 & 335 & \\
\hline
\end{tabular}

All percentages are column percents within the variable (gender, anatomical location and histological subtype)

${ }^{2}$ Comparison the data for cases $<45$ vs $\geq 45$

Thirty nine patients $(11.6 \%)$ developed gastric adenocarcinoma before 45 years of age. This young group was different from the overall group of patients in several respects: there was a predominance of women $(22,56.4 \%)$ compared to men $(17,43.6 \%)$, and a greater proportion of the tumors were of the diffuse histological subtype $(64.5 \%$ of the classified tumors). There were no differences regarding anatomic location (Table 3). The number of these young cases was too small to evaluate for trend over time.

\section{DISCUSSION}

In this study, we analyzed the occurrence of gastric adenocarcinoma over a period of 25 years in a tertiary care hospital which is the referral center for the central region of Rio Grande do Sul State, in Southern Brazil. We found that the overall frequency of finding gastric cancer has not changed, and it is still a disease of the elderly which predominates in men. Moreover, the cardia/non-cardia distribution has not changed, but the distribution of intestinal and diffuse histological subtypes has changed significantly over this time period.

Although the overall incidence of gastric cancer in RS is declining, the overall frequency of finding gastric cancer per 100 upper gastrointestinal endoscopies in this series did not changed over the 25 year-period. The reasons for the generalized decline in gastric cancer rates are complex and not completely understood. Possible reasons include a more varied and affluent diet, better food preservation, including refrigeration, as well as the control of Helicobacter pylori ( $H$ pylori) infection. A possible explanation for the unchanged rate in this series could be that most patients coming to our hospital are from low social classes, with low income and with few or no sanitation facilities. Refrigeration is not always available, and tobacco smoking is more common than in populations with higher income and education levels.

The mean age and male predominance of the patients in our series is similar to that in other reports. Throughout the world, stomach cancer is a disease of the elderly population with the predominance in $\operatorname{men}^{(3,30)}$.

Trend analyses in our study showed no changes in mean age or gender proportions over the years. The explanation for male predominance in our series is unknown, but one factor which could contribute is the greater exposure of this gender to smoking. An additional environmental factor which may be related to the development of gastric cancer in Southern Brazil is the consumption of large quantities of salted red meat in "churrasco", a form of barbecue. It is been reported that the consumption of red meat is more common in the male population ${ }^{(2,18)}$. High consumption of red meat has previously been shown to be a risk factor for gastric cancer in Uruguay ${ }^{(2)}$ and other countries ${ }^{(11)}$. The intake of salty foods is also a well-established risk factor for gastric cancer ${ }^{(26,28)}$, and a recent study found this association only in males ${ }^{(21)}$, raising one more possible explanation for the prevalence of gastric adenocarcinoma in men in our population.

Tumor location is important in gastric cancer because of its therapeutic and prognostic implications. Tumors in the middle third of the stomach have a better prognosis after the surgical treatment, while proximal tumors are more aggressive and have a worse prognosis ${ }^{(9,25)}$. Several studies have reported an increasing prevalence of proximal lesions in the last decades ${ }^{(3,6,10,12,22,24,27,31)}$, including a report from the Brazilian Southeastern region that observed slight increase in incidence of proximal gastric cancer, although not so remarkable as it is reported ${ }^{(14)}$. We did not observe this trend in our study. In our series, distal tumors were 6 times as common as proximal tumors, and this proportion was relatively constant throughout the 25 years. Similar data has been found in other studies, with no clear explanation ${ }^{(12)}$. As noted previously, inhabitants of the Southern region of Brazil have a high consumption of red meat, which has been associated with an increased risk of distal, but not proximal, gastric adenocarcinoma ${ }^{(11)}$. This could be one possible explanation for the unchanging location of gastric cancer in this region.

The histopathological subtypes described by Nevalainen ${ }^{(16)}$ differ not only in histological appearance, but also in epidemiology, therapy and prognosis. In our study, the more prevalent subtype overall was intestinal adenocarcinoma. Similar to other reports ${ }^{(24,29)}$, however, we observed a rising trend of the diffuse subtype, which in our series was most apparent after the year 2001. The reasons for this increase are still speculative. There were no significant differences in 
the trends of diffuse or intestinal subtypes by gender over the 25 years of our study.

A recent report from the US found an increasing incidence of diffuse type gastric cancer in the cardia, as well as decreasing incidence of both histological types in the more distal stomach ${ }^{(29)}$. This association of the Lauren ${ }^{(17)}$ subtypes with anatomical location is not considered in most studies that report the changing trends of proximal can$\operatorname{cer}^{(10,12,22,24,27,31)}$. In our study, both histological subtypes had a similar prevalence in both cardia and non-cardia adenocarcinoma throughout the 25 -years period. Therefore, we did not observe that any histological type had a preference for any location.

Gastric cancer is an uncommon condition in young patients, but recent reports from the US suggest that the incidence in Caucasian patients younger than 40 years has increased ${ }^{(4)}$. In our series, we did not have enough young cases to evaluate the trend in cases over time, but we compared patients less than 45 years old with older patients and we found that gastric cancer in the younger patients was more common in women, and the diffuse histological subtype predominated. Other studies have also observed a female and a diffuse subtype predominance in young gastric cancer patients, in contrast to older patients, in whom males and the intestinal subtype still predominate ${ }^{(1,23)}$. H pylori is considered the most important risk factor for development of gastric cancer, and its prevalence has declined over the past decades ${ }^{(7,20)}$, so a further decline in gastric cancer incidence in young patients would be expected. However other factors which may have influenced gastric cancer risk have also changed during this time, including the widespread use of proton pump inhibitors (PPIs), changes in the gastric microbial environment after loss of $\mathrm{H}$ pylori colonization, and lifestyle risk factors (smoking and diet $)^{(8)}$. All of these issues require further elucidation.

Our study has several limitations. As in all retrospective studies, some pertinent data was missing, including data related to H pylori infection, the use of PPIs, smoking, and diet. Another limitation of our study was that it was restricted to a single reference center, which may not be widely representative. However, the information reported here can be used to explore the relationship between the same variables and gastric cancer in other centers, in other populations. And in spite of these limitations, the present study contributes new information on the occurrence of the gastric adenocarcinoma and its anatomic and histological subtypes over a 25 year period of time in a distinct population, and raises new ideas for further studies.

\section{CONCLUSIONS}

The results of our study indicate that there was no significant change in the overall frequency, the mean age, the gender distribution, or the anatomic location of gastric adenocarcinomas in RS over the past 25 years. There was, however, a significant increase in the occurrence of the diffuse histological subtype and a decrease in the intestinal subtype, without a preference of either subtype for any location in the stomach. In patients under 45 years old, gastric cancer was more frequent in women, and the diffuse subtype predominated. Population-based studies are needed to confirm these findings and to elucidate the role of possible risk factors for proximal and distal gastric cancer in Southern Brazil.

\section{ACKNOWLEDGEMENTS}

The authors would like to thank Dr. Sanford M. Dawsey (Division of Cancer Epidemiology and Genetics, National Cancer Institute, National Institute of Health, Bethesda, MD, USA) for his comments and suggestions on earlier drafts of this report.

Rampazzo A, Motta GL, Fontana K, Fagundes RB. Tendência temporal do adenocarcinoma do estômago na região central do Rio Grande do Sul: o que mudou em 25 anos? Arq Gastroenterol. 2012;49(3): 179-83.

RESUMO - Contexto - O câncer gástrico é a quarta neoplasia mais frequente no mundo e sua incidência varia de acordo com a região estudada. É mais frequente nos países asiáticos, principalmente Japão e China. No Brasil, é o terceiro e quinto câncer mais comum em homens e mulheres, respectivamente. Estas taxas são similares no Rio Grande do Sul e o principal tipo histológico é o adenocarcinoma. Objetivo - Investigar o comportamento deste câncer no período de 25 anos em um centro de referência na região central do Rio Grande do Sul. Métodos - Foram revisados os laudos das endoscopias digestivas altas realizadas no Hospital Universitário de Santa Maria, RS, entre 1986 e 2010. Avaliaram-se a incidência, distribuição por faixa etária, sexo, subsítio anatômico e subtipo histológico do câncer gástrico ao longo deste período. Resultados - Entre 20.521 pacientes submetidos a endoscopia digestiva alta, no período estudado, foram identificados $335(1,6 \%)$ pacientes com adenocarcinoma gástrico. A idade média dos pacientes foi 62,4 ( $\pm 13,0)$ anos e 67,8\% pertenciam ao sexo masculino (razão homem:mulher de 2:1). Câncer da cárdia ocorreu em 14,3\% e não-cárdico em $85,7 \%$ dos casos. Na classificação de Lauren, $48,1 \%$ foram classificados como subtipo intestinal em 48,1\% e difuso em 40,9\%. Não houve diferenças na distribuição por idade ou sexo em relação à localização anatômica ou subtipo histológico, assim como na proporção dos subtipos histológicos em relação à localização anatômica. No período de 25 anos não houve mudanças na distribuição anatômica, porém foi observada redução significativa do subtipo intestinal e aumento do subtipo difuso $(P=0,02)$. No estrato abaixo de 45 anos foram identificados $39(11,6 \%)$ pacientes, com maior probabilidade de serem do sexo feminino e apresentarem tumor do subtipo difuso em relação ao total da série. Conclusões - No período de 25 anos, não houve mudanças significativas em relação à idade, distribuição por sexo ou na localização cárdica e não-cárdica do câncer gástrico nesta série de pacientes do sul do Brasil. Ocorreu uma redução significativa do subtipo intestinal e aumento acentuado do subtipo difuso. Nos pacientes abaixo de 45 anos, o câncer gástrico foi mais frequente em mulheres com predomínio do subtipo difuso.

DESCRITORES - Neoplasias gástricas, epidemiologia. Adenocarcinoma. Rio Grande do Sul. 


\section{REFERENCES}

1. Adán-Merino L, Gómez-Senent S, Froilán-Torres C, Suárez J, Martín-Arranz E, Larrauri J, Mora-Sanz P, Segura-Cabral J, Aldeguer-Martinez M. [Gastric adenocarcinoma in young adults: a comparative study with elderly patients]. Rev Gastroenterol Mex. 2010;75:253-60.

2. Aune D, De Stefani E, Ronco A, Ronco A, Boffetta P, Deneo-Pelegrini H, Acosta G, Medilaharsu M. Meat consumption and cancer risk: a case-control study in Uruguay. Asian Pac J Cancer Prev. 2009;10:429-36.

3. Brenner H, Rothenbacher D, Arndt V. Epidemiology of stomach cancer. Methods Mol Biol. 2009;472:467-77.

4. Camargo MC, Anderson WF, King JB, Correa P, Thomas CC, Rosemberg PS, Eheman CR, Rabkin CS. Divergent trends for gastric cancer incidence by anatomical subsite in us adults. Gut. 2011;60:1644-9.

5. Chatenoud L, Bertuccio P, Bosetti C, Levi F, Curado MP, Malvezzi M, Negri E, La Vechia C. Trends in cancer mortality in Brazil, 1980-2004. Eur J Cancer Prev. 2010;19:79-86.

6. Craanen ME, Dekker W, Blok P, Ferwerda J, Tytgat GN. Time trends in gastric carcinoma: changing patterns of type and location. Am J Gastroenterol. 1992;87:572-9.

7. De Mello ES, Melo CR. [Prevalence of the various types of gastritis in patients with upper dyspeptic symptoms]. Arq Gastroenterol. 1992;29:43-50.

8. De Vries AC, Kuipers EJ. Gastric cancer in young patients: clues on a possible separate entity requiring a watchful approach. J Gastroenterol Hepatol. 2011;26:1581-2.

9. Deans C, Yeo MS, Soe MY, Shabbir A, Ti TK, So JB. Cancer of the gastric cardia is rising in incidence in an Asian population and is associated with adverse outcome. World J Surg. 2011;35:617-24.

10. Ferlay J, Shin HR, Bray F, Forman D, Mathers C, Parkin DM. Estimates of worldwide burden of cancer in 2008: globocan 2008. Int J Cancer. 2010;127:2893-917.

11. Gonzalez CA, Jakszyn P, Pera G, Plebani M, Carneiro F, Nesi G, Berrino F, Sacerdote C, Tumino R, Panico S, Berglund G, Simán H, Nyrén O, Hallmans G, Martinez C, Dorronsoro M, Barricarte A, Navarro C, Quirós Jr Allen N, Key Tj, Day Ne, Linseisen J, Nagel G, Bergmann MM, Overvad K, Jensen MK, Tjonneland A, Olsen A, Bueno-de-Mesquita HB, Ocke M, Peeters PH, Numans ME, Clavel-Chapelon F, Boutron-Ruault MC, Trichopoulou A, Psaltopoulou T, Roukos D, Lund E, Hemon B, Kaaks R, Norat T, Riboli E. Meat intake and risk of stomach and esophageal adenocarcinoma within the European prospective investigation into cancer and nutrition (EPIC). J Natl Cancer Inst. 2006;98:345-54.

12. Hassan HA, Sharma VK, Raufman JP. Changing trends in gastric carcinoma at a university medical center: a twelve-year retrospective analysis. J Clin Gastroenterol. 2001;32:37-40.

13. Instituto Nacional do Cancer. Mortalidade 2011. http://mortalidade.inca.gov.br/ mortalidade. 2011.

14. Jacob CE, Gama-Rodrigues J, Bresciani CJ, Zilberstein B. Prosxcurchin I, Irya $\mathrm{K}$, Alves VA, Cecconello I. Trends in tumor location in gastric carcinoma over a 28-year period. Hepatogastroenterology. 2007;54:1297-301.
15. Jass Jr Sobin LH, Watanabe H. The World Health Organization's histologic classification of gastrointestinal tumors. A commentary on the second edition. Cancer. 1990;66:2162-7.

16. Lauren P. The two histological main types of gastric carcinoma: diffuse and so-called intestinal-type carcinoma. An attempt at a histo-clinical classification. Acta Pathol Microbiol Scand. 1965;64:31-49.

17. Lauren PA, Nevalainen TJ. Epidemiology of intestinal and diffuse types of gastric carcinoma. A time-trend study in Finland with comparison between studies from high- and low-risk areas. Cancer. 1993;71:2926-33.

18. Matos E, Brandani A. Review on meat consumption and cancer in South America. Mutat Res. 2002;506-507:243-9.

19. Misumi A, Murakami A, Harada K, Baba K, Akagi M. Definition of carcinoma of the gastric cardia. Langenbecks Arch Chir. 1989;374:221-6.

20. Muller LB, Fagundes RB, Moraes CC, Rampazzo A. [Prevalence of Helicobacter pylori infection and gastric cancer precursor lesions in patients with dyspepsia] Arq Gastroenterol. 2007;44:93-8.

21. Murata A, Fujino Y, Pham TM, Kubo T, Mizoue T, Tokui N, Matsuda S, Yoshimura T. Prospective cohort study evaluating the relationship between salted food intake and gastrointestinal tract cancer mortality in Japan. Asia Pac J Clin Nutr. 2010;19:564-71.

22. Popiela T, Kulig J, Kolodziejczyk P, Sierzega M. Changing patterns of gastric carcinoma over the past two decades in a single institution: clinicopathological findings in 1557 patients. Scand J Gastroenterol. 2002;37:561-7.

23. Santoro R, Carboni F, Lepiane P, Ettorre GM, Santoro E. Clinicopathological features and prognosis of gastric cancer in young European adults. Br J Surg. 2007;94:737-42.

24. Schmassmann A, Oldendorf MG, Gebbers JO. Changing incidence of gastric and oesophageal cancer subtypes in Central Switzerland between 1982 and 2007. Eur J Epidemiol. 2009;24:603-9.

25. Sheen-Chen SM, Chou CW, Chen MC, Chen FC, Chen YS, Chen JJ. Adenocarcinoma in the middle third of the stomach--an evaluation for the prognostic significance of clinicopathological features. Hepatogastroenterology. 1997;44:1488-94

26. Tsugane S. Salt, salted food intake, and risk of gastric cancer: epidemiologic evidence. Cancer Sci. 2005;96:1-6.

27. Wang X, Wu CX, Zheng Y, Wang JJ. [Time trends and characteristics of gastric cancer incidence in urban Shanghai]. Zhonghua Liu Xing Bing Xue Za Zhi. 2007;28:875-80.

28. Wang XQ, Terry PD, Yan H. Review of salt consumption and stomach cancer risk: epidemiological and biological evidence. World J Gastroenterol. 2009;15:2204-13.

29. Wu H, Rusiecki JA, Zhu K, Potter J, Devesa SS. Stomach carcinoma incidence patterns in the United States by histologic type and anatomic site. Cancer Epidemiol Biomarkers Prev. 2009;18:1945-52.

30. Yang L. Incidence and mortality of gastric cancer in China. World J Gastroenterol. 2006; 12:17-20

31. Zhou Y, Zhang Z, Zhang Z, Wu J, Ren D, Yan X, Wang Q, Wang Y, Wang H, Zhang J, Zhu X, Yang Y, Luo C, Guo X, Tang C, Qiao L. A rising trend of gastric cardia cancer in Gansu province of China. Cancer Lett. 2008;269:18-25.

Received 23/1/2012 Accepted 16/3/2012. 